REGARDS

SUR LEECONOMIE ALLEMAND

BULLETIN ECONOMIQUE DU CIRAC
Regards sur l'économie allemande

Bulletin économique du CIRAC

112 | 2014

Varia

\title{
Mémoire de l'Europe
}

\section{(2) OpenEdition}

1 Journals

Édition électronique

URL : https://journals.openedition.org/rea/4669

DOI : 10.4000/rea.4669

ISBN : 978-2-8218-0826-3

ISSN : 1965-0787

Éditeur

CIRAC

Édition imprimée

Date de publication : 28 avril 2014

Pagination : 40

ISSN : 1156-8992

Référence électronique

"Mémoire de l'Europe », Regards sur l'économie allemande [En ligne], 112 | avril 2014, mis en ligne le 30 avril 2014, consulté le 10 mars 2022. URL : http://journals.openedition.org/rea/4669 ; DOI : https:// doi.org/10.4000/rea.4669

Ce document a été généré automatiquement le 10 mars 2022

(c) CIRAC 


\section{Mémoire de l'Europe}

\section{RÉFÉRENCE}

SCHMIDT Helmut, Mein Europa, Hoffmann und Campe Verlag, Munich, 2013, 368 p.

1 «Il n'est écrit dans nulle Bible que l'Union européenne, dans sa forme actuelle, vivra jusqu'à la fin du $\mathrm{XXI}^{\mathrm{e}}$ siècle. Les chefs de gouvernement ne sont absolument pas conscients du sérieux de la situation actuelle ». L'ex-chancelier Helmut SCHMIDT parle d'expérience. Il est l'un des maîtres-artisans de la construction européenne et nous livre ici nombre de discours et articles qui en avaient accompagné les étapes. Et à la fin de ce vibrant plaidoyer pour l'Europe qui nous remet en mémoire tout le long, patient et difficile travail de construction réalisé, l'impitoyable donnant-donnant comme tous les acquis que nous avons tendance à oublier, H. Schmidt, l'Ancien, débat avec Joschka Fischer (génération d'après-guerre) des défis que nous avons à relever d'urgence aujourd'hui. Une réflexion destinée à nous accompagner durant la campagne des élections au Parlement européen. (ib) 